\title{
Anti-phospholipid syndrome in seven leprosy patients with thrombotic events on corticosteroid and/or thalidomide regimen: insights on genetic and laboratory profiles
}

\author{
Sebastian Vernal[1], Maria Jose Franco Brochado ${ }^{[1]}$, Roberto Bueno-Filho ${ }^{[1]}$, \\ Paulo Louzada-Junior ${ }^{[2]}$ and Ana Maria Roselino ${ }^{[1]}$
}

\author{
[1]. Divisão de Dermatologia, Departamento de Clínica Médica, Faculdade de Medicina de Ribeirão Preto, \\ Universidade de São Paulo, Ribeirão Preto, SP, Brasil. \\ [2]. Divisão de Imunologia, Departamento de Clínica Médica, Faculdade de Medicina de Ribeirão Preto, \\ Universidade de São Paulo, Ribeirão Preto, SP, Brasil.
}

\begin{abstract}
Introduction: Corticosteroids and/or thalidomides have been associated with thromboembolism events (TBE) in multibacillary (MB) leprosy. This report aimed to determine genetic and laboratory profiles associated with leprosy and TBE. Methods: Antiphospholipid antibodies (aPL), coagulation-related exams, prothrombin and Leiden's factor V mutations, and B2-glycoprotein-I (B2GPI) Val247Leu polymorphism were assessed. Results: Six out of seven patients with leprosy were treated with prednisone and/or thalidomide during TBE and presented at least one positive aPL. All patients presented B2GPI polymorphism, and one showed prothrombin mutation. Conclusions: Corticosteroid or thalidomide adverse effects and aPL and B2GPI polymorphisms may cause TBE in patients with MB leprosy.
\end{abstract}

Keywords: Leprosy. Antiphospholipid antibodies. Beta-2-glycoprotein-I. Factor V Leiden. Prothrombin. Thromboembolism.

Leprosy immune reactions are systemic inflammatory complications that commonly occur when introducing a treatment. However, these reactions may also occur at any time during the disease course and can relapse intermittently over several years ${ }^{1,2}$. Leprosy immune reactions are classified by the World Health Organization (WHO) as type 1 (T1R or reverse reaction) and type 2 (T2R or erythema nodosum leprosum) and are manifested by multibacillary (MB) patients ${ }^{1,2}$. T1R typically occurs in patients with borderline spectrum, whereas T2R mainly occurs in patients with borderline lepromatous (BL) and lepromatous leprosy (LL) (Ridley-Jopling classification) $)^{1,2}$.

Reverse reaction is a delayed-type hypersensitive reaction caused by increased cell-mediated immunity to Mycobacterium leprae antigens. T1R may damage nerves and is mainly treated with corticosteroids ${ }^{1}$. Erythema nodosum leprosum (ENL), the main symptom of T2R, is caused by a humoral immune response to M. leprae and results in direct deposits of antigenantibody immune complexes in the vessels and tissues ${ }^{1}$. The

Corresponding author: Dra. Ana Maria Roselino.

e-mail: amfrosel@fmrp.usp.br

Received 25 May 2017

Accepted 24 August 2017 treatment of ENL varies depending on the country and leprosy center treatment due to restrictions and costs implicated in the use of some drugs ${ }^{2}$. Corticosteroids and/or thalidomide are the preferred medications to suppress ENL²; notwithstanding, both of them are related to several adverse events (AEs) ${ }^{2}$. Thromboembolic phenomena (TEP) are well-documented AEs of thalidomide, a drug used as monotherapy to treat myeloma. The risk of TEP is even higher when thalidomide is associated with corticosteroids or chemotherapy ${ }^{2}$. In the last decade, some reports have described the occurrence of TEP due to ENL treatment with thalidomide ${ }^{3}$.

Although the prothrombotic AE of thalidomide is clearly defined, other intrinsic factors may also cause TEP associated with leprosy. Indeed, high frequency of antiphospholipid antibodies (aPL), especially anti-cardiolipin (aCL) and anti- $\beta 2$ glycoprotein-I (anti-ß2GPI), has been observed in patients with leprosy $^{4-6}$. The presence of aPL is not necessarily associated with antiphospholipid syndrome (APS), which is known to manifest thrombotic events. Nevertheless, some authors have debated whether some clinical features of leprosy, such as Lucio's reaction, TR1 and TR2 immune reactions, and gangrene, may manifest APS $^{6-8}$.

This report aimed to identify the clinical and laboratory data related to coagulation, including factor $\mathrm{V}$ Leiden and prothrombin G20210A polymorphisms, and therapeutic aspects in seven patients with leprosy who experienced thrombotic 
events. Additionally, aPL and B2-glycoprotein-I Val247Leu polymorphism were investigated to differentiate intrinsic thrombophilia and APS.

Patients were diagnosed at the University Hospital of Ribeirão Preto Medical School, University of São Paulo, Southeastern Brazil, from 1997 to 2006. Data were collected from medical charts and electronic database system of the University Hospital. Leprosy was diagnosed and confirmed based on WHO's recommendations ${ }^{1}$. Both WHO and RidleyJoplin classifications were used to classify leprosy ${ }^{1}$.

Anti-phenolic glycolipid 1 (Anti-PGL1) IgM was measured using in-house enzyme-linked immunosorbent assay (ELISA) as described previously ${ }^{9}$; $\operatorname{IgM}$ and $\operatorname{IgG}$ aCL and anti-B2P levels were determined using commercial ELISA kits (QUANTA Lite, INOVA, USA). Lupus anticoagulants (LA) were analyzed using Viperquik LA-Check test and Kaolin clotting time (KCT). The coagulation factors, i.e., anti-thrombin III, proteins $\mathrm{C}$ and $\mathrm{S}$, and fibrinogen, were measured in the peripheral blood using chromogenic methods during thrombotic episodes.

Factor V Leiden and G20210A mutation of prothrombin gene were analyzed using polymerase chain reaction-restriction fragment length polymorphism (PCR-RFLP). The Val247Leu polymorphism of the 32 -glycoprotein-I gene was determined as described previously ${ }^{10}$.

Informed consent was obtained from all patients. This study was approved by the local Human Ethics Committee (\#3605/2006) in accordance with the ethical standards of the
Helsinki Declaration (1964, amended most recently in 2008) of the World Medical Association.

This report included seven leprosy patients with thrombotic events. Tables $\mathbf{1}$ and $\mathbf{2}$ and Figure $\mathbf{1}$ summarize the clinical, laboratory, and therapeutic data. Patients' median age was 48 years (youngest, 26 years; oldest, 70 years); six of them were males. The seven MB patients corresponded to the BB, BL, and LL classifications (one, four, and two, respectively). Five of the patients presented TR2 at the onset of leprosy, corresponding to BL and LL classifications; another BL patient was affected by TR1, as commonly described ${ }^{2}$. The patient with BB leprosy did not present any associated reaction. The most common thrombotic events were deep venous thrombosis (DVT) that occurred in three patients and DVT associated with pulmonary thromboembolism (PTE) that occurred in the other three patients. One patient presented with PTE only. Among the six patients with leprosy reaction, five were treated with thalidomide plus corticosteroids during the thrombotic episode, whereas one patient was treated with corticosteroids alone. None of the patients were active smokers. Except for case 4, tests for thrombophilia did not show any genetic predisposition (Figure 1).

Herein, we will discuss the seven cases in more detail. Case 1 was a 45 -year-old Caucasian male patient clinically diagnosed as having LL form of leprosy. He presented several ENL and multiform erythema outbreaks since the diagnosis. He developed DVT on the right limb in March 1999 when he was still under multi-drug treatment (MDT) for leprosy, including

TABLE 1: Clinical data of seven patients with multibacillary leprosy who experienced thrombotic events.

\begin{tabular}{|c|c|c|c|c|c|c|c|}
\hline & Patient 1 & Patient 2 & Patient 3 & Patient 4 & Patient 5 & Patient 6 & Patient 7 \\
\hline Sex & Male & Male & Female & Male & Male & Male & Male \\
\hline Ethnicity & Caucasian & Caucasian & Caucasian & Mulatto & Caucasian & Caucasian & Caucasian \\
\hline $\begin{array}{l}\text { Ridley-Jopling } \\
\text { Classification }\end{array}$ & LL & BL & LL & BB & $\mathrm{BL}$ & $\mathrm{BL}$ & $\mathrm{BL}$ \\
\hline $\begin{array}{l}\text { Leprosy immune } \\
\text { reaction }\end{array}$ & TR2 & TR2 & TR2 & None & TR2 & TR2 & TR1 \\
\hline Bacilloscopy & Positive & Positive & Positive & Negative & Positive & Positive & Positive \\
\hline $\begin{array}{l}\text { Thrombotic episode } \\
\text { (Date) }\end{array}$ & $\begin{array}{l}\text { DVT in RL } \\
\text { (03.1999) }\end{array}$ & $\begin{array}{c}\text { DVT in LL } \\
\text { PE in Left Lung (both lobes) } \\
(01.2003 \& 03.2004)\end{array}$ & $\begin{array}{c}\text { PTE } \\
(06.2003)\end{array}$ & $\begin{array}{l}\text { DVT in RL } \\
\text { PTE bilateral } \\
\text { (01.2004) }\end{array}$ & $\begin{array}{l}\text { DVT in RL } \\
(04.2004)\end{array}$ & $\begin{array}{l}\text { DVT in LL } \\
(09.2004)\end{array}$ & $\begin{array}{l}\text { DVT in LL } \\
\text { PTE } \\
(05.2007)\end{array}$ \\
\hline $\begin{array}{l}\text { Use of thalidomide and/ } \\
\text { or corticosteroids during } \\
\text { the thrombotic episode }\end{array}$ & Both & Both & Both & No & Both & Both & Prednisone \\
\hline $\begin{array}{l}\text { Prescription of MDT } \\
\text { during the thrombotic } \\
\text { episode }\end{array}$ & Yes & Yes & No & Yes & Yes & No & Yes \\
\hline
\end{tabular}

LL: Lepromatous leprosy; BL: borderline leprosy; BB: borderline-borderline leprosy; TR1: leprosy reaction type 1; TR2: leprosy reaction type 2; DVT: deep venous thrombosis; RL: right leg; LL: left leg; PTE: pulmonary thromboembolism; MDT: multi-drug treatment. 
TABLE 2: Laboratory data of seven patients with multibacillary leprosy who experienced thrombotic events.

\begin{tabular}{|c|c|c|c|c|c|c|c|}
\hline & Patient 1 & Patient 2 & Patient 3 & Patient 4 & Patient 5 & Patient 6 & Patient 7 \\
\hline $\begin{array}{l}\text { (Date) IgM anti-PGL1 } \\
\text { (index) }(\mathrm{NV}<1.0)\end{array}$ & $\begin{array}{l}0.2000) 0.3 \\
(04.2005) 0.5\end{array}$ & $\begin{array}{l}(10.2002) 25.0 \\
(03.2004) 1.5 \\
(09.2004) 4.6\end{array}$ & $\begin{array}{l}(05.2000) 1.7 \\
(04.2002) 1.0 \\
(05.2002) 0.5\end{array}$ & 0.8 & (01.2004) 1.5 & $\begin{array}{l}(07.2001) 26.8 \\
(10.2004) 1.8 \\
(11.2004) 1.5\end{array}$ & $\begin{array}{l}0.5 \\
0.2006) \\
(12.2006) 0.4\end{array}$ \\
\hline $\begin{array}{l}\text { (Date) IgG aCL } \\
(\mathrm{GPL})(\mathrm{NV}<15)\end{array}$ & $\begin{array}{l}(04.2004)<15 \\
(04.2005)<15\end{array}$ & $\begin{array}{l}(01.2004) 35.0 \\
(08.2004) 32.0 \\
(09.2004) 34.0\end{array}$ & $\begin{array}{l}(06.1999)<15 \\
(04.2001) 49.0 \\
(05.2001)<15 \\
(08.2004)<15 \\
(10.2004)<15\end{array}$ & $\begin{array}{l}(03.2005)<15 \\
(04.2005) 16.3 \\
(07.2005) 18.8\end{array}$ & $\begin{array}{l}(04.2004) 44.0 \\
(09.2004)<15 \\
(06.2005)<15\end{array}$ & $\begin{array}{l}(04.2005)<15 \\
(06.2005)<15\end{array}$ & $(05.2007)<15$ \\
\hline $\begin{array}{l}\text { (Date) IgM aCL } \\
(\mathrm{MPL})(\mathrm{NV}<12.5)\end{array}$ & $\begin{array}{l}(04.2004)<12.5 \\
(04.2005)<12.5\end{array}$ & $\begin{array}{l}(01.2004) 125.0 \\
(08.2004) 85.0 \\
(09.2004) 94.0\end{array}$ & $\begin{array}{c}(01.2001) \\
<12.5 \\
(05.2001) 70.0 \\
(08.2004) 54.0 \\
(10.2004) 68.0\end{array}$ & $\begin{array}{l}(03.2005)<12.5 \\
(04.2005)<12.5 \\
(07.2005)<12.5\end{array}$ & $\begin{array}{l}(04.2004) 34.0 \\
(08.2004)<12.5 \\
(06.2005)<12.5\end{array}$ & $\begin{array}{l}(04.2005) \\
\quad<12.5 \\
\\
(06.2005) \\
\quad<12.5\end{array}$ & $\begin{array}{l}(05.2007) \\
\quad<12.5\end{array}$ \\
\hline $\begin{array}{l}\text { (Date) Lupus } \\
\text { anticoagulants }\end{array}$ & $\begin{array}{l}(04.2004)(-) \\
(06.2005)(+) \\
(12.2005)(+)\end{array}$ & Not done & $(09.2005)(+)$ & $(07.2005)(-)$ & Not done & $\begin{array}{l}(09.2004)(-) \\
(04.2005)(-) \\
(06.2005)(+) \\
(09.2005)(+)\end{array}$ & Not done \\
\hline $\begin{array}{c}\text { (Date) lgG anti - ß2GPI } \\
(\mathrm{SMU})(\mathrm{NV}<10)\end{array}$ & $(09.2005)<10$ & $(09.2005)<10$ & $(09.2005)<10$ & $(09.2005)<10$ & $(09.2005)>100$ & $(09.2005)<10$ & $(05.2007)<10$ \\
\hline $\begin{array}{l}\text { (Date) IgM anti- } \\
\text { ß2GPI (NV < 12) }\end{array}$ & $(09.2005)<12$ & $(09.2005)<12$ & $(09.2005)>100$ & $(09.2005)<12$ & $(09.2005)>100$ & $(09.2005)<12$ & $(05.2007)<12$ \\
\hline $\begin{array}{c}\text { Anti-thrombin III (NV } \\
70-130 \%)\end{array}$ & 107 & 73 & 86 & 101 & Not done & 114 & Not done \\
\hline $\begin{array}{c}\text { Protein C (NV 70- } \\
130 \%)\end{array}$ & 150 & Not done & 115 & 68 & Not done & 128 & Not done \\
\hline $\begin{array}{c}\text { Protein S (NV 50- } \\
\qquad 130 \%)\end{array}$ & 70 & Not done & 88 & Not done & Not done & 95 & Not done \\
\hline Kaolin clotting time & Negative & Positive & Negative & Negative & Not done & Positive & Not done \\
\hline $\begin{array}{l}\text { Fibrinogen }(\mathrm{mg} / \mathrm{dL}) \\
\quad(\mathrm{NV} 200-400)\end{array}$ & Not done & 394 & 326 & 800 & Not done & 454 & Not done \\
\hline $\begin{array}{l}\text { Factor V Leiden (NV } \\
+/+)\end{array}$ & $+/+$ & $+/+$ & $+/+$ & $+/+$ & $+/+$ & $+/+$ & $+/+$ \\
\hline $\begin{array}{l}\text { Prothrombin G20210A } \\
\text { mutation (NV -/-) }\end{array}$ & $-/-$ & $-1-$ & $-1-$ & $+/-$ & $-1-$ & $-1-$ & $-/-$ \\
\hline $\begin{array}{l}\text { ß2GPI Leu247Val } \\
\text { Polymorphism }\end{array}$ & $\begin{array}{l}\text { Heterozygote } \\
\text { (Haplotype 1\&4) }\end{array}$ & $\begin{array}{l}\text { Heterozygote } \\
\text { (Haplotype } \\
1 \& 4)\end{array}$ & $\begin{array}{l}\text { Homozygote } \\
\text { Val/Val } \\
\text { (Haplotype 4) }\end{array}$ & $\begin{array}{l}\text { Heterozygote } \\
\text { (Haplotype } \\
1 \& 4)\end{array}$ & $\begin{array}{l}\text { Heterozygote } \\
\text { (Haplotype } \\
1 \& 4)\end{array}$ & $\begin{array}{l}\text { Homozygote } \\
\text { Val/Val } \\
\text { (Haplotype 4) }\end{array}$ & $\begin{array}{l}\text { Homozygote } \\
\text { Val/Val } \\
\text { (Haplotype } \\
4 \& 7 \text { ) }\end{array}$ \\
\hline
\end{tabular}

IgM: immunoglobulin M; NV: normal value; PGL1: Phenolic Glycolipid 1; aCL: anti-Cardiolipin; GPL: standard IgG cardiolipin units; MPL: standard IgM cardiolipin units; B2GPI: ß2-glycoprotein-I; Leu: leucine; Val: valine.

prednisone $(60 \mathrm{mg} /$ day) and thalidomide $(300 \mathrm{mg} /$ day), due to ENL. Laboratorial tests were performed 5 years after the DVT episode and yielded negative results for aCL and anti-ß2GPI. LA was negative in 2004, but turned positive in 2005. LA has been a stronger risk factor for thrombosis than positive aCL or anti- $\beta 2 \mathrm{GPI}$ in purely obstetrical APS ${ }^{11}$. Protein $\mathrm{C}$ was the only abnormal laboratory test result related to coagulation. The primary effect of activated protein $\mathrm{C}$ is to inactivate the $\mathrm{Va}$ and VIIIa coagulation factors, which are necessary to efficiently generate thrombin and activate factor X. Genetic deficiency of protein $\mathrm{C}$ has been related to DVT; however, the protein $\mathrm{C}$ level was above the normal range in this case. 

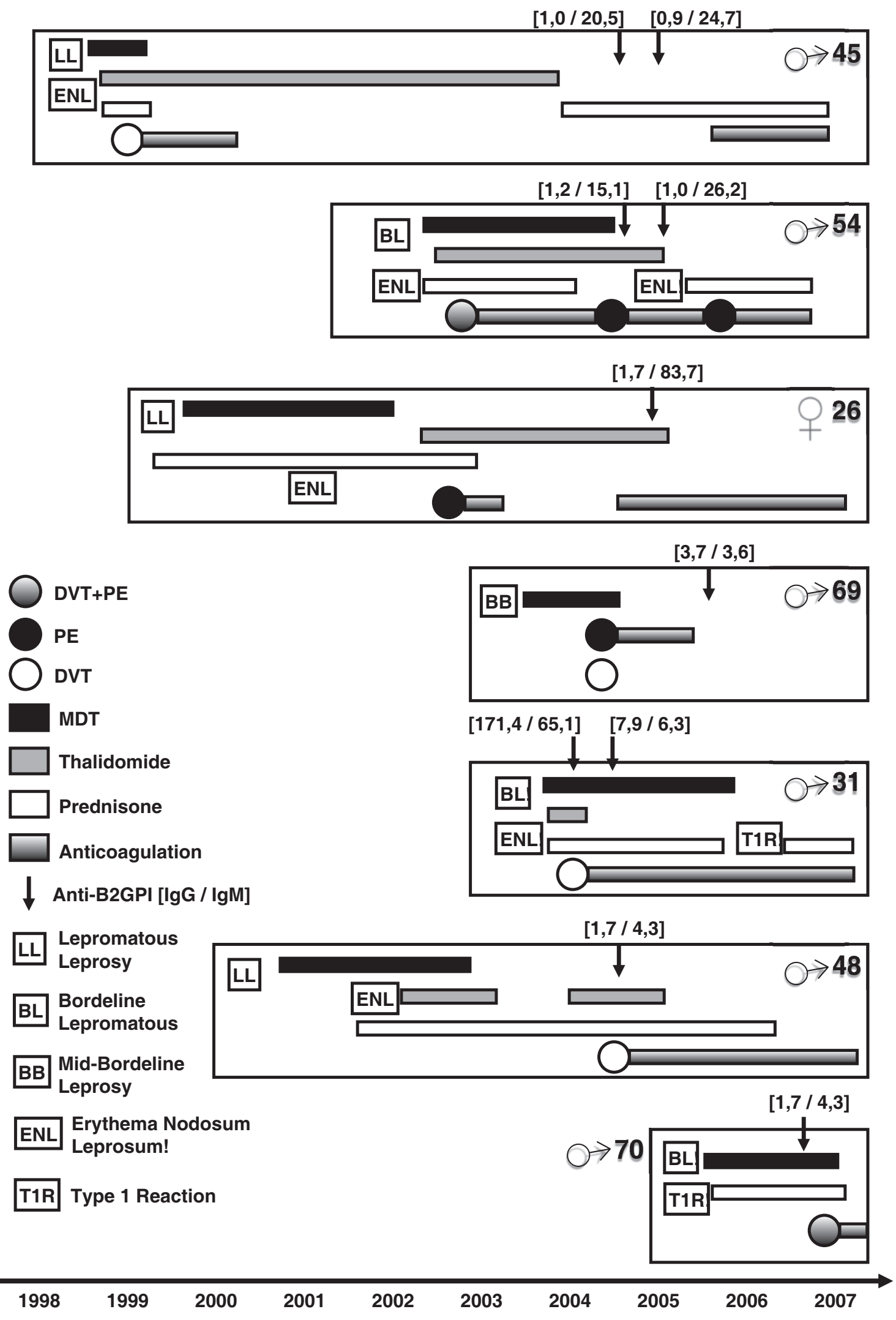

FIGURE 1: Timeline overview of thrombotic events and laboratory data of the seven patients with leprosy. 
Case 2 was a 54-year-old Caucasian male patient diagnosed as having BL in 2002. He had been presenting multiform bullous erythema and ENL outbreaks since the diagnosis. In 2003 and 2004, he presented DVT in the left limb associated with PTE in the upper and lower lobes of the left lung, respectively. Both episodes occurred during the use of MDT plus prednisone (10-60mg/day) and thalidomide (100-200 mg/day). During the PTE episode in 2004, IgM and IgG aCL increased. In infectious diseases, aPL antibodies tend to be IgM type because the infectious agent might trigger the autoimmune response. However, IgG aCL has also been detected in patients with leprosy ${ }^{12}$. The only laboratory test related to abnormal coagulation was the KCT. This was expected from the positive aPL result, which would interfere with the accumulation of prothrombinase complex ${ }^{11}$.

The third patient was a 26-year-old Caucasian female diagnosed as having LL in 2001. In the last two years, she had been chronically using prednisone due to misdiagnosis of lupus erythematosus. In 2001, ENL outbreaks occurred when she used prednisone and an alternative MDT scheme. Thalidomide was introduced in May 2003. In July 2003, she presented PTE while using prednisone (40mg/day) and thalidomide (200mg/ day). She was not using any other medications at the time, not even contraceptive pills. aPL screening during PTE revealed high IgM and IgG aCL and anti-ß2GPI levels, and LA tests yielded positive results.

The fourth patient was a 69 -year-old mulatto male who had been diagnosed as having BB leprosy in 2003. In January 2004, he experienced a DVT in the right limb and bilateral PTE while using MDT and hydrochlorothiazide. High IgG aCL (18.8 GPL) was confirmed 18 months after the thrombotic event. He also presented high levels of fibrinogen $(800 \mathrm{mg} / \mathrm{dL})$, which may be elevated in response to inflammation or tissue injury ${ }^{13}$ during leprosy. Heterozygosis for the prothrombin G20210A gene was demonstrated.

The fifth patient was a 31-year-old Caucasian male diagnosed as having BL in 2003 and who had been experiencing ENL outbreaks since the diagnosis. In 2004, he had DVT in the right limb while using MDT associated with prednisone (30 mg/ day) and thalidomide (300 mg/day). High IgM and IgG aCL were confirmed at the time of DVT. Six months later, IgM and $\mathrm{IgG} \mathrm{aCL}$ turned and remained negative in 2005. High levels of $\operatorname{IgM}$ and $\operatorname{IgG}$ anti- $\beta 2 \mathrm{GPI}$ antibodies were also observed 1.5 years after the DVT episode. Unfortunately, laboratory tests related to coagulation were not performed. Assessment for thrombophilia did not show any genetic predisposition.

The sixth patient was a 48-year-old Caucasian male who was diagnosed as having BL and ENL in 2001. In 2004, he developed DVT in the left limb while using thalidomide $(100 \mathrm{mg} /$ day). IgM and IgG aCL and anti- $\beta 2 \mathrm{GPI}$ levels were within the normal limits and LA was negative during and after the thrombotic episode, but LA became positive 1 year later. Like the fourth case, this patient had high fibrinogen levels as expected in an inflammatory scenario ${ }^{13}$. KCT was also positive due the presence of aPL, as expected ${ }^{11}$.

The last patient was a 70-year-old Caucasian male diagnosed as having BL in 2006, with T1R. In 2007, he developed DVT in the left limb and PTE during an alternative MDT scheme associated with prednisone $(60 \mathrm{mg} /$ day). IgM and $\mathrm{IgG}$ aCL and aPL were normal. Regrettably, LA and laboratory tests related to coagulation were not performed.

Regarding the $\beta 2$ GPI genetic polymorphism evaluated in haplotypes 1 and 4, three patients presented Val/Val homozygosis (cases 4, 6, and 7), and the other three presented Leu247Val heterozygosis (cases 1, 2, 3, and 5). High frequency of $\beta 2 \mathrm{GPI}$ Val/Val homozygosis has been described in Brazilian leprosy patients as compared to controls. Furthermore, MB patients with high IgM anti- $\beta 2$ GPI levels presented higher $\beta 2$ GPI Val/Val homozygosis frequency than the controls ${ }^{6,10}$. $\beta 2 \mathrm{GPI}$ Val/Val homozygosis seems to represent a higher risk factor than Leu247Val heterozygosis for the development of APS in the general population ${ }^{6,10}$. However, this has not been confirmed yet, and larger studies attributing higher risk of APS to Val/Val homozygosis should be conducted.

Only one patient (case 4) had mutated prothrombin G20210A gene, which independently conferred a 2.8-fold increased risk of DVT in both sexes and in all age groups ${ }^{14}$. This patient presented a thrombotic event without leprosy reaction outbreaks even though he was not treated with thalidomide and/or corticosteroid. Interestingly, he was the only patient in this case series who had genetic polymorphism for thrombophilia. Therefore, genetic thrombophilia could explain the development of a thrombotic event even without using thalidomide and/or corticosteroids. Moreover, the presence of $\mathrm{aCL}$ and $\beta 2 \mathrm{GPI}$ Leu $247 \mathrm{Val}$ heterozygosis may have contributed to the development of DVT in this patient.

Some reports of thrombotic events due to the use of thalidomide and/or corticosteroids in MB leprosy patients with ENL are notorious ${ }^{5-9}$. However, serum tests or assessment of patients' genetic background regarding the diagnosis of intrinsic thrombophilia was not conducted in these studies. Here, we analyzed several pro-thrombotic factors in seven MB patients from Southeastern Brazil, not only to determine acquired risk factors due to leprosy and AEs of the drugs but also the manifestation of APS and $\beta 2$ GPI Leu247Val polymorphism. Based on our results, the Brazilian Ministry of Health has recommended the use of aspirin $\left(100 \mathrm{mg} /\right.$ day) during the treatment of $\mathrm{ENL}^{15}$, which could also be recommended in other countries where thalidomide and/ or corticosteroids are the first-line therapy for T2R.

\section{Acknowledgments}

We thank the biologists Flavia Vieira and Sandra Silva Rodrigues Santos for their technical laboratory support.

\section{Conflict of interest}

All authors declared to have no conflicts of interest.

\section{Financial support}

This research did not receive any specific grant from funding agencies in the public, commercial, or not-for-profit sectors. SV received $\mathrm{PhD}$ scholarship from CAPES (Coordenação de Aperfeiçoamento de Pessoal de Nivel Superior). 


\section{REFERENCES}

1. World Health Organization. WHO Expert Committee on Leprosy. World Health Organ Tech Rep Ser. 2012(968):1-61, 1 p following 61.

2. Walker SL, Balagon M, Darlong J, Doni SN, Hagge DA, Halwai V, et al. ENLIST 1: An International Multi-centre Cross-sectional Study of the Clinical Features of Erythema Nodosum Leprosum. PLoS Negl Trop Dis. 2015;9(9):e0004065.

3. Petiti-Martin GH, Villar-Buill M, de la Hera I, Fuertes L, BurguésCalderón M, Rivera-Díaz R, et al. Deep vein thrombosis in a patient with lepromatous leprosy receiving thalidomide to treat leprosy reaction. Actas Dermosifiliogr. 2013;104(1):67-70.

4. Hojnik M, Gilburd B, Ziporen L, Blank M, Tomer Y, Scheinberg MA, et al. Anticardiolipin antibodies in infections are heterogenous in their dependency on beta 2-glycoprotein I: analysis of anticardiolipin antibodies in leprosy. Lupus. 1994;3(6):515-21.

5. Ribeiro SL, Pereira HL, Silva NP, Souza AW, Sato EI. Anti- $\beta 2-$ glycoprotein I antibodies are highly prevalent in a large number of Brazilian leprosy patients. Acta Reumatol Port. 2011;36(1):30-7.

6. Brochado MJ, Figueiredo JF, Mendes-Junior CT, Louzada-Junior P, Kim OM, Roselino AM. Correlation between beta-2-glycoprotein I gene polymorphism and anti-beta-2 glycoprotein I antibodies in patients with multibacillary leprosy. Arch Dermatol Res. 2010;302(8):583-91.

7. Bakos L, Correa CC, Bergmann L, Bonamigo RR, Muller LF. Antiphospholipid antibodies thrombotic syndrome misdiagnosed as Lucio's phenomenon. Int J Lepr Other Mycobact Dis. 1996;64(3):320-3.
8. Akerkar SM, Bichile LS. Leprosy \& gangrene: a rare association; role of anti phospholipid antibodies. BMC Infect Dis. 2005;5:74.

9. Moura RS, Calado KL, Oliveira ML, Bührer-Sékula S. Leprosy serology using PGL-I: a systematic review. Rev Soc Bras Med Trop. 2008;41(suppl 2):11-8

10. Brochado MJ, Nascimento MM, Louzada Junior P, Figueiredo JF, Roselino AM. Val247Leu polymorphism of beta2 glycoprotein 1 gene may justify the genesis of anti beta2GP1 antibodies and antiphospholipid syndrome in multibacillary leprosy. An Bras Dermatol. 2009;84(4):355-9.

11. Amin NM. Antiphospholipid syndromes in infectious diseases. Hematol Oncol Clin North Am. 2008;22(1):131-43.

12. Giannakopoulos B, Krilis SA. The pathogenesis of the antiphospholipid syndrome. N Engl J Med. 2013;368(11):1033-44.

13. Green F, Humphries S. Control of plasma fibrinogen levels. Baillieres Clin Haematol. 1989;2(4):945-59.

14. Margaglione M, Brancaccio V, Giuliani N, D'Andrea G, Cappucci $\mathrm{G}$, Iannaccone $\mathrm{L}$, et al. Increased risk for venous thrombosis in carriers of the prothrombin $\mathrm{G} \rightarrow \mathrm{A} 20210$ gene variant. Ann Intern Med. 1998;129(2):89-93.

15. Ministério da Saúde (MS). Secretaria de Vigilância em Saúde. Departamento de Vigilância de Doenças Transmisíveis. Diretrizes para vigilância, atenção e eliminação da hanseníase como problema de saúde pública. Manual técnico-operacional. Brasília: MS; 2016. 60p. Disponível em: http://www.saude.gov.br/svs2016. Accessed on May 5, 2017 